\title{
Heme Synthesis in Hereditary Hemolytic Anemias: Decreased $\delta$-Aminolevulinic Acid Synthetase in Hemoglobin Köln Disease
}

\author{
G. B. KOLSKI AND D. R. MILLER ${ }^{(41)}$ \\ Department of Pediatrics, Division of Pediatric Hematology-Oncology, New York Hospital-Cornell Medical Center, \\ New York, New York, USA
}

\section{Extract}

The activities of $\delta$-aminolevulinic acid (ALA) synthetase and ALA dehydratase in cord blood erythrocytes of newborn infants and peripheral blood red cells of patients with $\beta$-thalassemia major, $\beta$-thalassemia intermedia, hemoglobin Köln ( $\mathrm{Hb}$ Köln) disease, sickle cell anemia, and pyruvate kinase deficiency were studied. The activity of ALA dehydratase did not vary appreciably with the number of immature RBC (reticulocytes and nucleated red blood cells) or the severity of the hemolytic anemia except in pyruvate kinase deficiency. The activity of ALA synthetase was linearly correlated with the number of immature RBC $(r=0.974, p<$ 0.001 ). The ALA synthetase activity was significantly decreased in the $\mathbf{R B C}$ of $\mathrm{Hb}$ Köln $(p<\mathbf{0 . 0 1})$ when compared with the activity in immature $\mathrm{RBC}$ of newborns and of patients with pyruvate kinase deficiency, sickle cell anemia, and thalassemia intermedia.

\section{Speculation}

The decreased activity of ALA synthetase activity in thalassemia major and $\mathrm{Hb}$ Köln is postulated to be secondary to feedback inhibition of heme. The site of feedback inhibition is not at the RBC membrane but could be directly on ALA synthetase itself or at its synthetic step.

Heme has a key role in the synthesis of globin and is involved in the initiation and assembly of globin chains. Heme also controls its own synthesis by inhibiting the utilization of glycine at the ALA synthetase step and thus regulates the synthesis of both the heme and globin moieties of the hemoglobin molecule. Disorders in the formation of heme will be reflected in disturbed synthesis and assembly of globin; disorders in the synthesis of globin will affect the production of heme.

In hemoglobin Köln disease, an unstable hemoglobin hemolytic anemia is caused by a structural defect of the $\beta$-globin chains $\left(\beta^{98 \mathrm{~V}_{\mathrm{H}}} \mathrm{Met}^{\mathrm{M}}\right)$. Recent studies have indicated that the synthesis of $\mathrm{Hb}$ Köln tetramer is defective $(5,38)$ and that $\beta^{\mathrm{K} i \mathrm{\prime n}}$-globin chains are synthesized at one-fifth the rate of $\beta^{\mathrm{A}}$-chains (5). In $\beta$-thalassemia major decreased synthesis of structurally normal $\beta$-globin chains has been demonstrated (36) and in earlier, indirect studies, impaired heme synthesis was suggested $(2,3,7,28,34,36)$. Recently, decreased ALA synthetase activity has been demonstrated in $\beta$-thalassemia (32) using a direct assay. Similar studies in $\mathrm{Hb}$ Köln disease have not been reported.

The rate-determining step in the synthesis of heme involves the formation of ALA from succinyl coenzyme A and glycine. This reaction is catalyzed by the enzyme, ALA synthetase, which is present in the mitochondria of erythroid precursors but not in mature red blood cells. For this reason, most assays of ALA synthetase require large amounts of peripheral blood $(4,8,11,17)$ or bone marrow samples (1, 33-35). In 1970, Strand et al. (29) developed a microassay method for the determination of ALA synthetase. Using $100 \mu \mathrm{l}$ packed red blood cells, they found increased ALA synthetase activity in patients with congenital or acquired hemolytic anemia.

Applying this micromethod, we assayed the activity of ALA synthetase in peripheral blood reticulocytes in neonates and in patients with thalassemia syndromes, unstable hemoglobin hemolytic anemias, and other heriditary hemolytic anemias. The purpose of this study was to substantiate directly the earlier observations $(2,3,7,24,30,34)$ of decreased levels of ALA synthetase in $\beta$-thalassemia major, and to determine whether the decreased rate of globin chain synthesis in $\mathrm{Hb}$ Köln disease is associated with decreased activity of ALA synthetase. The activity of ALA dehydratase, the subsequent reaction in heme synthesis in which $2 \mathrm{~mol}$ ALA are converted to porphobilinogen, was also measured in these disorders.

\section{MATERIALS}

The radionuclide, $\left[5-{ }^{14} \mathrm{C}\right] \mathrm{ALA}-\mathrm{HCl}$ (specific activity 0.156 $\mathrm{mCi} / \mathrm{mg}$ ) was purchased from New England Nuclear; AmershamSearle supplied $2,3-{ }^{3} \mathrm{H}$-succinic acid (specific activity $250 \mathrm{mCi}$ / $\mathrm{mmol})$. Other chemicals were obtained from Sigma Chemical Company. Polyethylene columns ( 1 by $4 \mathrm{~cm}$ ) were purchased from Bio-Rad and filled with Dowex 1X-8 acetate (100-200 mesh and 200-400 mesh) and Dowex 50W-X4 acid (100-200 mesh).

\section{PATIENTS}

Twenty-five patients with hereditary hemolytic anemias and 10 normal newborns were evaluated. Previously published methods were used to confirm the diagnoses of pyruvate kinase (PK) deficiency (21), Hb Köln disease (20), and sickle cell anemia. These patients had not received blood transfusions in the 6 months prior to testing. Five patients with thalassemia major were transfusiondependent and received frozen or washed red blood cell transfusions every $2-3$ weeks. The five patients with thalassemia intermedia had homozygous $\beta$-thalassemia, had undergone splenectomy, but did not require transfusions of red blood cells to maintain a level of hemoglobin above 7-8 g/100 ml. Healthy, nonanemic adults served as normal control subjects. Informed consent was obtained from all subjects and/or their mothers.

\section{METHODS}

\section{PREPARATION OF ERYTHROCYTES}

The erythrocytes from the normal, full term newborn infants were obtained from cord blood and collected in heparin-containing tubes (39). From all other subjects, blood was collected from the antecubital vein into similar tubes, separated into two fractions, and cooled to $4^{\circ}$ immediately. The plasma and leukocytes were removed from one of the fractions after centrifugation at $4^{\circ}$ and $1,000 \times g$ for $10 \mathrm{~min}$. The erythrocytes were washed twice in 0.05 
M phosphate buffer, $\mathrm{pH} 7.4$, which contained $0.1 \mathrm{M} \mathrm{KCl}, 0.005 \mathrm{M}$ $\mathrm{MgCl}_{2}$, and $0.5 \mathrm{mM}$ EDTA. The leukocyte-free red cells were then twice alternately frozen in an acetone-Dry Ice bath and thawed for utilization in the assay for ALA synthetase. Whole blood from the second fraction was used in the assay of ALA dehydratase. Packed cell volume, hemoglobin, red blood cell, and reticulocyte counts were determined by standard methods.

\section{$\delta$-ALA DEHYDRATASE ASSAY}

The assay is a modification of the method of Mauzerall and Granick (19) in which a buffered substrate disc containing citrate buffer and $\delta$-ALA (Bio-Rad) was added to a test tube containing 1 $\mathrm{ml}$ doubly distilled water and then incubated for $15-30 \mathrm{~min}$. Whole blood $(0.1 \mathrm{ml})$ was added to a second tube containing $1.5 \mathrm{ml}$ doubly distilled water which was then incubated for $5 \mathrm{~min}$. The contents of the two tubes were mixed to initiate the reaction which was stopped after $60 \mathrm{~min}$ by the addition of $1.0 \mathrm{ml}$ trichloracetic acid (TCA) reagent (Bio-Rad). Equal volumes of the supernatant from the reaction mixture and Ehrlich's reagent were mixed and, after $8-12 \mathrm{~min}$, the absorbance was measured at $555 \mathrm{~nm}$ in a Beckman Acta III spectrophotometer. The porphobilinogen produced was determined using the extinction coefficient $\mathrm{E}_{555}=6.1 \times 10^{4} \mathrm{M}^{-1} \mathrm{~cm}^{-1}(19)$.

\section{$\delta$-ALA SYNTHETASE ASSAY}

The incubation mixture was that described by Strand et al. (29) and contained inhibitors of the tricarboxylic acid cycle and other pathways to prevent utilization of succinyl-CoA. Succinyl-CoA was formed from succinic acid and $\mathrm{CoA}$ using Escherichia coli-derived succinyl-CoA synthetase $\left(\begin{array}{ll}1.7 & \mathrm{U}\end{array}\right)$. Succinyl-CoA synthetase was purified by the method of Ramalay et al. (23) from $E$. coli grown in a 13 liter fermenter. Succinyl-CoA synthetase was assayed as described by Ramalay et al. (23). The appearance of the thioester bond of succinyl-CoA at $230 \mathrm{~nm}$ was monitored in a Gilford recording spectrophotometer and calculation of succinyl-CoA formation was based upon the $E_{230}$ of $4.5 \times$ $10^{3} \mathrm{M}^{-1}, \mathrm{~cm}^{-1}$ as determined by Stadtman (25).

Using $0.30 \mathrm{mM} \mathrm{Na}_{2}$ succinate with tritium at the 2 and 3 positions, radioactive ALA was produced from the following reactions.

Reaction 1

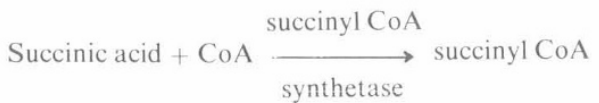

Reaction 2

\section{$\mathrm{COOH}$}
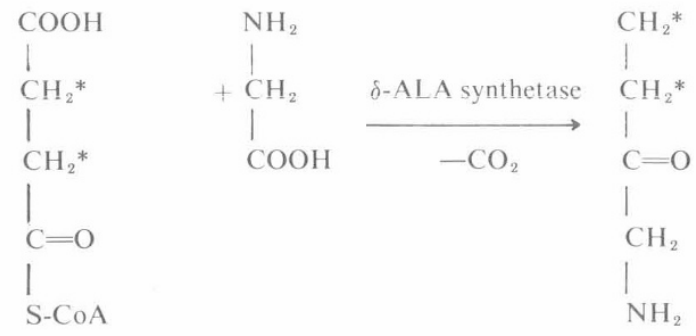

Succinyl-CoA Glycine

$\delta$-ALA

The incubation mixture contained the necessary cofactors for both succinyl-CoA synthetase and $\delta$-ALA synthetase. The reaction was stopped after $30 \mathrm{~min}$ with $0.1 \mathrm{ml} 25 \%$ TCA.

\section{ISOLATION OF ALA}

The isolation procedure was that described by Strand et al. (29) in which the incubation mixture was run through an anion exchange resin at $\mathrm{pH} 7$ to remove unreacted radioactive succinic acid. The eluate from the first column was then passed directly onto a cation exchange column at $\mathrm{pH} 4.6$ after treatment with Ehrlich's reagent. The chromatography and isolation procedures were monitored by using $\left[5-{ }^{14} \mathrm{C}\right] \mathrm{ALA}$ added to the incubation mixture to assess recovery using double label scintillation counting. The recovery was $70-80 \%$. The tritiated product moved consistantly with $\left[5-{ }^{14} \mathrm{C}\right] \mathrm{ALA}$.

\section{SCINTILLATION COUNTING}

Eluted samples were mixed with $10 \mathrm{ml}$ Aquasol from New England Nuclear and counted in a Hewlett-Packard or Beckman LS-250 liquid scintillation spectrometer. The counts obtained were corrected for counting efficiency, percentage of recovery, and the activity of the succinyl-CoA synthetase blank.

\section{RESULTS}

The blood of most patients was analyzed for both ALA synthetase and ALA dehydratase activity, and attempts were made to correlate the activity with the relative youth of the peripheral red blood cells.

\section{ALA DEHYDRATASE}

The data in Table 1 show that little change in the overall activity of ALA dehydratase occurs despite the tremendous variation in reticulocytosis. With the extreme reticulocytosis seen in the patients with PK deficiency, a 1.8-fold rise in the activity of ALA dehydratase is observed. However, the activity within each group did not show a correlation with the actual reticulocyte counts.

\section{ALA SYNTHETASE}

The red cells of patients with PK deficiency are not known to have a defect in heme synthesis. The patients with PK deficiency evaluated in this study had undergone splenectomy and all had reticulocyte counts of greater than $30 \%$. The values for patients should give a reasonable estimate of the "normal" ALA synthetase activity in an extremely young population of erythrocytes. The assays of ALA synthetase in normal individuals with reticulocyte counts of $1.0 \%$ or less were subject to considerable error. This was related to the presence of some ALA synthetase activity in the succinyl-CoA synthetase blank which was equivalent to the activity observed in samples containing $1.0 \%$ or fewer reticulocytes. Therefore, determinations of ALA synthetase were accurate only when the reticulocyte count was greater than $1 \%$. Because of the low reticulocyte counts occurring in infants between 1 week and 3 months of age, accurate measurement of the activity of ALA synthetase during this period of physiologic anemia was not feasible in small samples of peripheral blood.

Figure 1 shows the correlation of the ALA synthetase activity

Table 1. Activity of $\delta$-aminolevulinic acid (ALA) dehydratase in erythrocytes

\begin{tabular}{|c|c|c|c|}
\hline $\begin{array}{c}\text { No. } \\
\text { of } \\
\text { patients }\end{array}$ & Diagnosis & $\begin{array}{c}\text { Reticulocyte } \\
\text { count, } \\
\text { \% range }\end{array}$ & $\begin{array}{c}\text { ALA } \\
\text { dehydratase } \\
\text { activity, } \\
\mathrm{nm} / \mathrm{ml} \\
\mathrm{RBC} / \mathrm{hr} \\
\text { (mean } \pm \mathrm{SD} \text { ) }\end{array}$ \\
\hline 8 & Normal & $0.5-1.5$ & $720 \pm 200$ \\
\hline 21 & Newborns & $1.0-7.0$ & $860 \pm 220$ \\
\hline 12 & Thalassemia major & $0.2-10$ & $905 \pm 210$ \\
\hline 5 & Thalassemia intermedia & $6-16$ & $840 \pm 380$ \\
\hline 4 & Sickle cell disease & $4.7-34$ & $840 \pm 130$ \\
\hline 5 & Hemoglobin Köln disease & $8-16$ & $912 \pm 270$ \\
\hline 4 & Pyruvate kinase deficiency & $37-76$ & $1,300 \pm 90$ \\
\hline
\end{tabular}




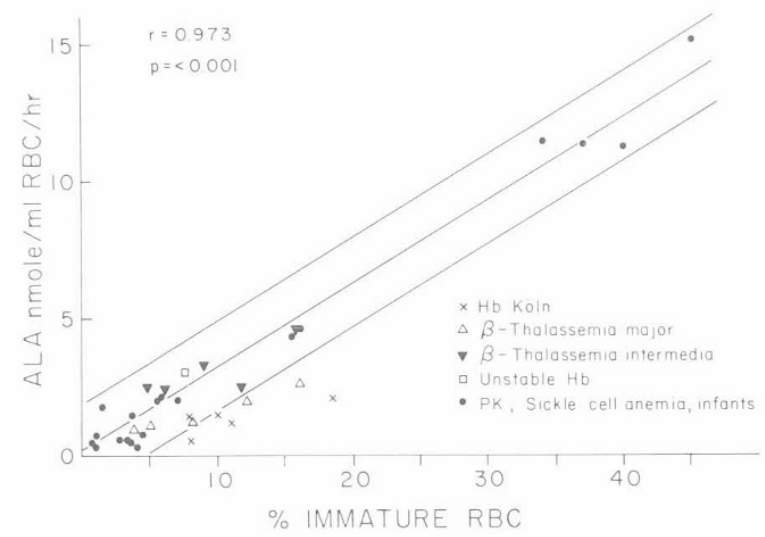

Fig. 1. Regression line for plot of $\delta$-aminolevulinic acid ( $A L A)$ synthetase activity, expressed as nanomoles per $\mathrm{ml} \mathrm{RBC} / \mathrm{hr}$, vs. percentage of reticulocytes and nucleated RBC in peripheral blood. Symbols for the various types of hereditary hemolytic anemias studied are given in the key. The symbol represents the mean of triplicate determinations for each patient. The correlation coefficient, $r=0.973$, is highly significant $(p<$ $0.001)$. PK: pyruvate kinase.

with immature red blood cells (immature cells included reticulocytes and nucleated red blood cells). The linear correlation is similar to that observed by Feldman and Lichtman (8). The correlation coefficient was $0.973(p<0.001)$ for the 25 patients in six categories (neonates, PK deficiency, sickle cell anemia, thalassemia intermedia, hereditary hemolytic anemia, and unstable hemoglobinopathy). As can be seen in Figure 1, a number of determinations fall below the regression line. These points correspond to patients with $\beta$-thalassemia major and $\mathrm{Hb}$ Köln disease. Table 2 shows the data presented as the ratio of ALA synthetase activity to immature RBC, the ALA synthetase or biosynthetic index for all patients studied. The ALA synthetic indexes (mean $\pm \mathrm{SE}$ ) of the different groups of patients are presented in Figure 2. The mean ALA synthetase index was significantly lower in $\mathrm{Hb}$ Köln disease $(p<0.01)$ and in $\beta$-thalassemia major $(p<0.02)$ than in the other hereditary hemolytic anemias or in newborns with equivalent reticulocytosis. The difference in means between the patients with $\mathrm{Hb}$ Köln disease and $\beta$-thalassemia major was not statistically significant nor were there any statistically significant differences between any of the other groups.

\section{DISCUSSION}

\section{ALA DEHYDRATASE}

The lack of variation in the ALA dehydratase activity despite a 150 -fold change in the reticulocyte count is important for the utilization of the ALA dehydratase assay in the diagnosis of lead poisoning (37). The enzyme is extremely sensitive to lead ion but the reticulocytosis which often accompanies lead poisoning will not cause raised leveis of ALA dehydratase activity.

The increase in ALA dehydratase activity occurring in pyruvate kinase deficiency associated with profound reticulocytosis is probably attributable to the fact that the population of red blood cells is much younger and has had less time for catabolism of the enzyme. The fact that the ALA dehydratase activity in human newborns and normal adults is the same may be contrasted to the situation in the mouse, in which the ALA dehydratase activity in the fetal liver is initially twice that found in the adult liver, decreases to well below adult levels in the days before delivery, and then slowly returns to the adult level (6).

\section{ALA SYNTHETASE}

The reliability of assays for ALA synthetase using radioactive succinate has been questioned recently by Aoki et al. (1). These investigators have developed a new method for measuring the activity of ALA synthetase in red blood cell precursors using $\left[{ }^{14} \mathrm{C}\right]$ succinyl-CoA, which they claim is more accurate than other assay systems. In related incorporation systems, the activity of ALA synthetase was 100 -fold greater when $\left[{ }^{14} \mathrm{C}\right]$ succinyl-CoA was used than when $\left[{ }^{14} \mathrm{C}\right]$ succinate was the substrate. However, Aoki's method was not compared with that of Strand and coworkers (29). Aoki et al. (1) found that the activity of ALA synthetase in erythroblasts $\left(300 \mathrm{nmol} / 10^{9}\right.$ erythroblasts $/ 30 \mathrm{~min}$ ) was 100 times greater than the activity of the enzyme measured in reticulocytes. In our study a value of $5 \mathrm{nmol} / 10^{9}$ reticulocytes $/ 30 \mathrm{~min}$ was calculated using estimates of mean corpuscular volume, known reticulocyte count, and the normal range of ALA synthetase activity. This value is $1 / 60$ of the activity of ALA synthetase in erythroblasts as measured by Aoki and would indicate the activity of ALA synthetase in reticulocytes as determined by the method of Strand et al. is comparable. The patients in this study with appreciable normoblastemia have been splenectomized. Their cells, although nucleated, would not be expected to have the same activity as bone marrow erythroid precursors since the cells in the

Table 2. $\delta$-Aminolevulinic acid $(A L A)$ synthetase activity in newborns and in hereditary hemolytic anemias

\begin{tabular}{|c|c|c|c|}
\hline $\begin{array}{l}\text { No. of } \\
\text { patients } \\
\text { or patient's } \\
\text { initials }\end{array}$ & $\begin{array}{l}\text { Reticulocyte } \\
\text { count, \% }\end{array}$ & Diagnosis & $\begin{array}{c}\text { ALA } \\
\text { synthetase } \\
\text { index }^{1} \\
(\text { mean } \pm \mathrm{SE})\end{array}$ \\
\hline 10 & $1.0-7.0$ & Newborns & $296 \pm 36$ \\
\hline 4 & $37-75$ & $\begin{array}{l}\text { Pyruvate kinase } \\
\text { deficiency }\end{array}$ & $249 \pm 44$ \\
\hline 4 & $8-34^{2}$ & $\begin{array}{l}\text { Sickle cell } \\
\text { anemia }\end{array}$ & $235 \pm 84$ \\
\hline$R C$ & 6.1 & $\begin{array}{l}\text { Thalassemia in- } \\
\text { termedia }\end{array}$ & 395 \\
\hline$E L$ & $16.2^{2}$ & $\begin{array}{l}\text { Thalassemia in- } \\
\text { termedia }\end{array}$ & 276 \\
\hline$C G$ & 6 & $\begin{array}{l}\text { Thalassemia in- } \\
\text { termedia }\end{array}$ & 345 \\
\hline$J S$ & 12 & $\begin{array}{l}\text { Thalassemia in- } \\
\text { termedia }\end{array}$ & 155 \\
\hline$F P$ & 8.8 & $\begin{array}{l}\text { Thalassemia in- } \\
\text { termedia }\end{array}$ & 330 \\
\hline$A G$ & 5.3 & $\begin{array}{l}\text { Thalassemia } \\
\text { major }\end{array}$ & 168 \\
\hline$J G$ & $17^{2}$ & $\begin{array}{c}\text { Thalassemia } \\
\text { major }\end{array}$ & 152 \\
\hline$J I$ & 5 & $\begin{array}{l}\text { Thalassemia } \\
\text { major }\end{array}$ & 227 \\
\hline$A N$ & 6.2 & $\begin{array}{c}\text { Thalassemia } \\
\text { major }\end{array}$ & 100 \\
\hline$M D$ & 1.6 & $\begin{array}{l}\text { Thalassemia } \\
\text { major }\end{array}$ & 210 \\
\hline$R M, \mathrm{Jr}$ & 18.7 & Hb Köln & 102 \\
\hline$R M, \mathrm{Sr}$ & 8.0 & Hb Köln & 67 \\
\hline$A M$ & 8.0 & Hb Köln & 169 \\
\hline$A M$ & 11.0 & Hb Köln & 103 \\
\hline$M M$ & 10.0 & Hb Köln & 142 \\
\hline$S D$ & 4.7 & $\begin{array}{l}\text { Hereditary hemo- } \\
\text { lytic anemia } \\
\text { (uncharacterized) }\end{array}$ & 442 \\
\hline$J V$ & 7.6 & $\begin{array}{l}\text { Unstable hemo- } \\
\text { globinopathy }\end{array}$ & 410 \\
\hline
\end{tabular}

${ }^{1}$ ALA synthetase index $=$ mean ALA synthetase activity $(\mathrm{nmol} / \mathrm{ml}$ $\mathrm{RBC} / \mathrm{hr}$ )/reticulocyte count + nucleated RBC count.

${ }^{2}$ Patients had 1-2\% nucleated RBC. 

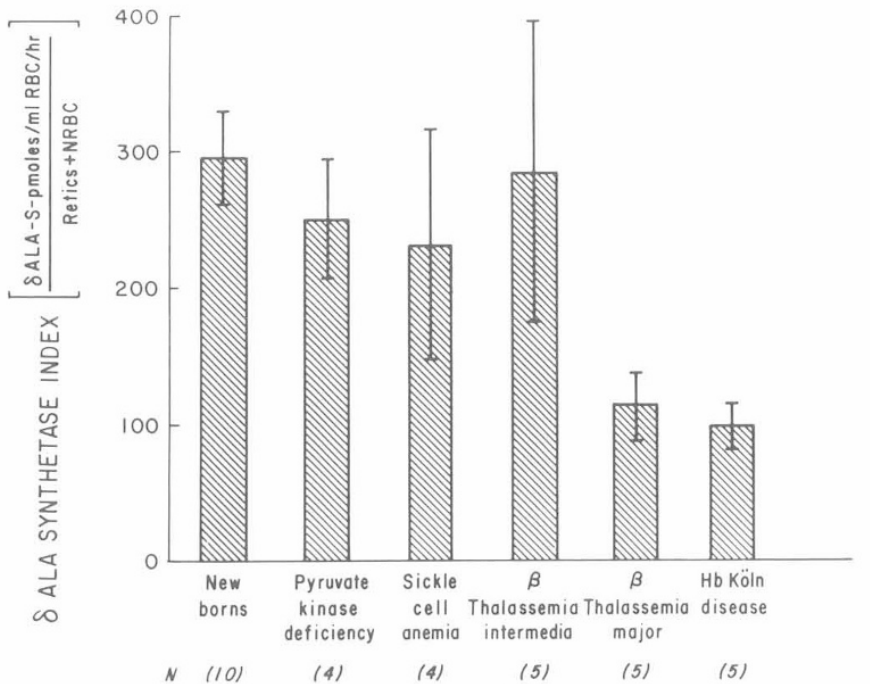

DIAGNOSIS

Fig. 2. $\delta$-Aminolevulinic acid $(A L A)$ synthetase index (biosynthetic index) in newborns, patients with $\mathrm{Hb}$ Köln disease, and other patients with hereditary hemolytic anemias. The bars and brackets represent the mean \pm SE for each group of patients studied.

peripheral blood are more mature orthochromic normoblasts, in which the activity of $\delta$-ALA synthetase is increased but is probably closer to that of the reticulocyte.

\section{$\beta$-THALASSEMIA MAJOR AND Hb KÖLN DISEASE}

The activity of ALA synthetase in the red cells of patients with $\beta$-thalassemia major is decreased and is consistent with the findings reported in other studies (30). Other investigators have detected decreased ALA synthetase utilizing indirect methods (2, $3,5,28,33,34)$. The decreased activity of ALA synthetase has been attributed to a direct feedback inhibition of ALA synthetase by heme $(2,14,17,18,27,36)$ and to an inhibitory feedback of globin on heme synthesis (27).

It is clear from this study that the patients with thalassemia intermedia do not have a significant decrease in ALA synthetase despite having homozygous $\beta$-thalassemia. Of the five patients studied with thalassemia intermedia, only one patient $(J S)$ had a level of ALA synthetase appreciably below average (ALA synthetase index 155). The patients with thalassemia intermedia are reasonably well compensated hematologically and do not have as great an imbalance in the production of globin chains (36). The fact that most patients with thalassemia intermedia have normal ALA synthetase activity may be an indication that the $\beta$-globin chain production, although decreased in rate, may be sufficient to prevent the accumulation of enough excess heme to inhibit ALA synthetase activity appreciably. The fact that two of five patients with thalassemia major have ALA synthetase activity values within the normal limits and that one of five patients with thalassemia intermedia has decreased ALA synthetase activity level may indicate that there is some overlap in the rate of $\beta$-globin chain production in patients with thalassemia intermedia and thalassemia major.

In $\mathrm{Hb} \mathrm{Köln}$ disease, ineffective erythropoiesis, and an abnormal rate of $\beta$-chain production (38) have been described, but information on iron utilization and heme synthesis is not available. The serum iron and total iron-binding capacity of patients with $\mathrm{Hb}$ Köln disease are normal and in this respect they differ from patients with thalassemia major and sideroblastic anemias. The molecular defect in $\mathrm{Hb} \mathrm{Köln}\left(\beta^{9 \mathrm{VVal}} \cdot\right.$ Met $\left.^{2}\right)$ is characterized by dissociation of heme from the structurally abnormal $\beta$-chains and oxidative denaturation of globin $(5,38)$. The released heme and the decreased $\beta$-Köln production may act in concert to produce levels of heme which inhibit ALA synthetase activity.

There is no evidence that globin has a feedback inhibitory effect on ALA synthetase activity. Experiments by Kappas and Granick (12) in cultures of liver cells showed that heme may have a repressor effect on ALA synthetase before translation. In Hb Köln disease and $\beta$-thalassemia, the observed decrease in ALA synthetase activity may be secondary to an earlier repression by heme of the synthetic machinery for ALA synthetase. The amount of heme present early in hemoglobin synthesis in more immature red blood cells may be a function of the instability of the abnormal hemoglobin and the magnitude of the defect in globin chain synthesis. Although Ponka and Neuwirt (22) have proposed that heme exerts an effect on its own synthesis by inhibiting the membrane transport of iron and glycine, this mechanism cannot explain our findings which are based upon as assay performed on hemolysates.

\section{SUMMARY}

Decreased ALA synthetase activity, the rate-limiting step in the synthesis of heme, has been observed in patients with $\mathrm{Hb}$ Köln disease, an unstable hemoglobin hemolytic anemia. In patients with other hereditary hemolytic anemias and in newborns the acitivty of ALA synthetase correlated with the number of reticulocytes and nucleated red blood cells.

\section{REFERENCES AND NOTES}

1. Aoki, Y., Urata, G., Wada, O., and Takaku, F.: Measurement of $\delta$ aminolevulinic acid synthetase activity in human erythroblasts. J. Clin. Invest., 53: 1326 (1974)

2. Bannerman, R. M.: Abnormalities of heme and pyrrole metabolism in thalassemia. Ann. N. Y. Acad. Sci., 1/9: 503 (1964).

3. Bannerman, R. M., Grinstein, M., and Moore, C. V.: Haemoglobin synthesis in thalassaemia; in-vitro studies. Brit. J. Haematol., 5: 102 (1959)

4. Chisolm. J. J.: Determination of $\delta$-aminolevulinic acid in plasma. Anal. Biochem., 22: 54 (-1968)

5. Dacie, J. V., Grimes, A. J., Meisler, A., Steingold, L., Hemsted, E. H., Beaver G. H., and White, J. C.: Hereditary Heinz body anaemia: A report of studies of five patients with mild anaemia. Brit. J. Haematol., 10: 388 (1964)

6. Doyle, D., and Schimke, R. T.: The genetic and developmental regulation of hepatic $\delta$-aminolevulinate dehydratase in mice. J. Biol. Chem., 244: 5449 (1969).

7. Erlandson, M. E., Wehman, J., Stern, G., Hilgartner, M., and Smith, C. H. Heme synthesis in thalassemia: Defect in conversion of glycine to $\delta$ aminolevulinate. Amer. J. Dis. Child., 102: 590 (1961).

8. Feldman, F., and Lichtman, H. C.: $\delta$-Aminolevulinate synthetase activity in the human reticulocyte. Biochim. Biophys. Acta, 14l: 653 (1967).

9. Grayzel, A. I., Horchner, P., and London, I. M.: The stimulation of globin synthesis by heme. Proc. Nat. Acad. Sci. U.S.A.. 55: 650 (1966).

10. Heinda, M. E., and Goldwasser, E.: Studies on the control of hemoglobin formation in marrow cells. Ann. N. Y. Acad. Sci., 149: 412 (1968)

11. Irving, E. A , and Elliott, W. H.: A sensitive radiochemical assay method for ALA synthetase. J. Biol. Chem., 244: 61 (1969).

12. Kappas, A., and Granick, S.: Steroid induction of porphyrin synthesis in liver cell cultures. J. Biol. Chem., 243: 346 (1968).

13. Kappas, A., Levere, R. D., and Granick, S.: Regulation of porphyrin and heme systhesis. Sem. Hematol. 5: 323 (1968).

14. Karibian, D., and London, I. M. Control of heme synthesis by feedback inhibition. Biochem. Biophys. Res. Commun., 18: 243 (1965).

15. Kramer, S., Vilpen, E., Becker, D., Zail, S. S., and Mitz, J.: Relationship between haem and globin synthesis by erythroid precursors in refractory normoblastic anemia. Scand. J. Haematol., 6: 293 (1969).

16. Lascelles, J., and Altshuler, T.: Mutant strains of Rhodopseudomonas spheroids lacking $\delta$-ALA synthetase. J. Bacteriol., 98: 721 (1969).

17. Lewis, M.: Glycine decarboxylation as an assay for erythrocyte ALA synthesis. J. Appl. Physiol., 3l: 76 (1971).

18. London, I. M., Bruns, G. P., and Karibian, D.: The regulation of hemoglobin synthesis and the pathogenesis of some hypochromic anemias. Medicine, 43 789 (1964).

19. Mauzerall, D., and Granick, S.: The occurrence and determination of $\delta$ aminolevulinic acid and porphobilinogen in urine. J. Biol. Chem., 219: 435 (1956).

20. Miller, D. R., Weed, R. I., Stamatoyannopolous, G., and Yoshida, A. Hemoglobin Köln disease occurring as a fresh mutation: Erythrocyte metabolism and survival. Blood, 38: 715 (1971).

21. Paglia, D. E., Valentine, W. N., Baughan, M. A., Miller, D. R. Reed, C. F., and McIntyre, O. R.: An inherited molecular lesion of erythrocyte pyruvate 
kinase: Identification of a kinetically aberrant enzyme associated with premature hemolysis. J. Clin. Invest., 47: 1929 (1968).

22. Ponka, P., and Neuwirt, J.: Use of reticulocytes with high non-haem iron pool for studies of regulation of haem synthesis. Bri. J. Haematol., 19: 593 (1970).

23. Ramalay, R. F., Bridges, W. A., Moyer, R. W., and Boyer, P. D.: The preparation, properties and reactions of succinyl coenzyme A synthetase and its phosphorylated form. J. Biol. Chem., 242: 4287 (1967).

24. Sahettini, F., Costa, S., Zimbalatti, F., and Fanciulli, G.: Hemoglobin synthesis from thalassemia reticulocytes: In vitro studies with iron-59 and glycine $2-C^{14}$ Ann. Paediat., 207: 345 (1966)

25. Stadtman, E. R.: Methods Enzymol., 3: 931 (1957).

26. Sterner, M., Baldini, M., and Dameshek, W.: Heme synthesis defect in "refractory" anemia with ineffective erythropoiesis. Blood, 22: 810 (1963).

27. Steiner, M., and Baldini, M.: Regulation of hemoglobin synthesis in normal erythroid cells. Blood, 30: 865 (1967).

28. Steiner, M., Baldini, M., and Dameshek, W.: Enzymatic defects of heme synthesis in thalassemia. Ann. N. Y. Acad. Sci., 119: 548 (1964).

29. Strand, L. J., Swanson, A. L., Manning, J., Branch, S., and Marver, H. S. Radiochemical microassay of $\delta$-aminolevulinate synthetase in hepatic and erythroid tissues. Ann. Biochem., 47: 457 (1970).

30. Takaku, F., and Nakao, K.: $\delta$-Aminolevulinic acid synthetase activity in erythroblasts of patients with sideroblastic anemia. Life Sci., 10: 721 (1971).

31. Takaku, F., Wada, O., Sassa, S., and Nakao, K.: Heme synthesis in normal and leukemic leukocytes. Cancer Res., 28: 1250 (1968).

32. Takaku, F., Yano, Y., Aoki, Y., Nakao, K., and Wada, O.: $\delta$-Aminolevulinic acid synthetase activity of human bone marrow erythroid cells in various hematological disorders. Tokoku J. Exp. Med., 107: 217 (1972).

33. Vavra, J. D., and Mayer, V. K.: In vitro porphyrin synthesis by human blood: Porphyrin synthesis by thalassemia erythrocytes. J. Lab. Clin. Med., 63: 754 (1964).

34. Vavra, J. D., Mayer, V. K., and Moore, C. V.: In vitro heme synthesis by human blood: Abnormal heme synthesis in thalassemia major. J. Lab. Clin. Med., 63: $736(1964)$

35. Vavra, J. D., and Poff, S. A.: Heme and porphyrin synthesis in sideroblastic anemia. J. Lab. Clin. Med., 63: 904 (1967).

36. Weatherall, D. J., and Clegg, J. B.: Thalassemia Syndromes, Ed. 2, p. 37 (Blackwell Scientific Publications, Oxford, 1972).

37. Weissberg, J. B., Lipshutz, F., and Oski, F. A.: $\delta$-Aminolevulinic acid dehydrogenase activity in circulating blood cells. N. Engl. J. Med., 284: 565 (1971).

38. White, J. M., and Brain, M. C.: Defective synthesis of an unstable haemoglobin Haemoglobin Köln ( $\left.\beta^{98 \mathrm{Val}-\mathrm{Met}}\right)$. Brit. J. Haematol., 18: 195 (1970).

39. Becton-Dickinson Co., E. Rutherford, N. J.

40. This research was supported by the Health Research Council of the City of New York (Contract U-2372), The Children's Blood Foundation, and Clinical Research Center Grant 2M01 RR0047 15.

41. Requests for reprints should be addressed to: D. R. Miller, M.D., Division of Pediatric Hematology-Oncology, New York Hospital-Cornell Medical Center. 525 E. 68th St. New York, N. Y. 10021 (USA).

42. Accepted for publication January 28, 1976.

\section{Corrigendum}

On p. 367 of the April 1976 issue of this journal, included in the Program and Abstracts of the Annual Meeting of the American Pediatric Society and the Society for Pediatric Research. St. Louis, Missouri, April 28 30, 1976, appears abstract No. 395 entitled "Origin of Chromosomal Abnormalities: Evidence for Delayed Fertilization in Meiotic Nondisjunction." Dr. John B. Mailhes, listed as one of the authors, had earlier requested his name be removed from these data. As this information was not made available to the publisher in time to delete his name, Dr. Mailhes now requests members of the medical and scientific community to dissociate his name from the above cited abstract. 